\title{
Whole-Transcriptome Sequencing: A Powerful Tool for Vascular Tissue Engineering and Endothelial Mechanobiology
}

\author{
Anton G. Kutikhin ${ }^{1, *}$, Maxim Yu. Sinitsky ${ }^{1}{ }^{\mathbb{D}}$, Arseniy E. Yuzhalin ${ }^{2}$ and Elena A. Velikanova ${ }^{1}$ \\ 1 Research Institute for Complex Issues of Cardiovascular Diseases, 6 Sosnovy Boulevard, \\ Kemerovo 650002, Russia; sinimu@kemcardio.ru (M.Y.S.); veliea@kemcardio.ru (E.A.V.) \\ 2 Department of Oncology, Cancer Research UK and Medical Research Council Oxford Institute for Radiation \\ Oncology, University of Oxford, Old Road Campus Research Building, Roosevelt Drive, \\ Oxford OX3 7DQ, UK; arseniy.yuzhalin@oncology.ox.ac.uk \\ * Correspondence: kytiag@kemcardio.ru; Tel.: +7-960-907-70-67
}

Received: 19 January 2018; Accepted: 19 February 2018; Published: 21 February 2018

\begin{abstract}
Among applicable high-throughput techniques in cardiovascular biology, whole-transcriptome sequencing is of particular use. By utilizing RNA that is isolated from virtually all cells and tissues, the entire transcriptome can be evaluated. In comparison with other high-throughput approaches, RNA sequencing is characterized by a relatively low-cost and large data output, which permits a comprehensive analysis of spatiotemporal variation in the gene expression profile. Both shear stress and cyclic strain exert hemodynamic force upon the arterial endothelium and are considered to be crucial determinants of endothelial physiology. Laminar blood flow results in a high shear stress that promotes atheroresistant endothelial phenotype, while a turbulent, oscillatory flow yields a pathologically low shear stress that disturbs endothelial homeostasis, making respective arterial segments prone to atherosclerosis. Severe atherosclerosis significantly impairs blood supply to the organs and frequently requires bypass surgery or an arterial replacement surgery that requires tissue-engineered vascular grafts. To provide insight into patterns of gene expression in endothelial cells in native or bioartificial arteries under different biomechanical conditions, this article discusses applications of whole-transcriptome sequencing in endothelial mechanobiology and vascular tissue engineering.
\end{abstract}

Keywords: high-throughput techniques; whole-transcriptome sequencing; RNA sequencing; cardiovascular diseases; endothelial mechanobiology; vascular tissue engineering; shear stress; cyclic strain; endothelial cells; endothelial progenitor cells

\section{Background}

Over the last decades, cardiovascular diseases have remained a leading cause of death worldwide, however, there has been a notable decrease in both age-standardized death rates and age-standardized, disability-adjusted life years per 100,000 population [1,2]. The abovementioned decline is largely due to progress in drug discovery and development, improvements in interventional cardiology and cardiovascular surgery, and the widespread implementation of evidence-based medicine that increases the availability and efficacy of cardiovascular care. In line with clinical advances, there is an abundance of ongoing basic and translational research intended to develop novel, versatile tools for cardiovascular medicine. This involves a number of scientific fields, such as molecular and cell biology, tissue engineering, personalized medicine, and nanomedicine.

The advent of high-throughput techniques (e.g., next-generation sequencing, proteomic arrays, and high-resolution mass spectrometry) has revolutionized biomedical research. It is now possible to 
uncover the multiple signaling pathways responsible for both physiological and pathological processes, and to pinpoint the molecular culprits of human disease. Such an approach has been actively employed in cancer research [3-5], atherosclerosis [6-8], chronic obstructive pulmonary disease [9], chronic kidney disease [10-13], endocrine disorders [14-16], autoimmune disorders [17,18], and neurodegenerative disorders [19-21]. Moreover, the integration of these data has led to the development of network biology and high-throughput drug screening [22-30]. Applying high-throughput methods frequently requires a collaboration between specialists from different fields, including omics, bioinformatics, life sciences, health sciences, and engineering.

Current cardiovascular surgery requires a small-diameter $(\leq 6 \mathrm{~mm})$ vascular graft for both arterial replacement and bypass surgery, yet this clinical need is still unmet [31-35]. Unfortunately, biostable synthetic vascular grafts have demonstrated poor results, reporting patency rates of $40 \%$ at six months and only $25 \%$ at three years postimplantation [32]. This is due to thrombosis and intimal hyperplasia secondary to a lack of endothelialization, low blood flow, and compliance mismatch [33,35]. Other reasons include infection, calcification, and the formation of pseudoaneurysms [31,34]. In addition, such grafts lack the capacity for adaptive growth and often result in a repeated surgery and unacceptable long-term outcomes [31,32]. This is of particular concern for pediatric patients with congenital heart disease, who frequently undergo vascular graft surgery at a young age [32].

Vascular tissue engineering has emerged as a promising approach for producing mechanically competent and biocompatible small-diameter vascular substitutes [31]. Most research in this field deploys polymer tubular scaffolds to provide a surface for cell attachment, proliferation, and migration, resulting in the formation of new vascular tissue and followed by the degradation of the scaffold [36]. Clinical demands for ready-to-use, biodegradable, small-diameter vascular grafts are present in all fields of cardiovascular surgery; e.g., heart surgery (treatment of coronary artery disease), vascular surgery (distal revascularization of lower limbs), neurosurgery (repair of intracranial arteries), pediatric cardiovascular surgery (treatment of congenital heart disease), and microsurgical reconstruction after severe hand traumas [31].

To minimize the risk of thrombosis and inflammation, vascular grafts should be covered by a monolayer of autologous endothelial cells (ECs); this also meets the concept of personalized medicine, which has been rapidly developing during the last decade [37-44]. As mature ECs have a relatively low proliferation rate [45], endothelial progenitor cells (EPCs) are actively used to induce endothelialization of the tubular scaffolds in vitro [46-48]. Autologous EPCs can be obtained by differentiation of peripheral blood-derived mononuclear cells cultured on fibronectin-coated dishes in endothelial basal medium supplemented with fetal calf serum, epidermal growth factor, vascular endothelial growth factor 165, basic fibroblast growth factor, insulin-like growth factor 1, hydrocortisone, ascorbic acid, and heparin [49-52], or by direct isolation from the blood utilizing magnetic-activated cell sorting [53-55].

According to research, shear stress preconditioning promotes endothelialization [51,56-62] and further differentiation of EPCs into mature ECs [51,57,58,62-74] that contain both anti-thrombotic and anti-atherosclerotic phenotypes [58,65,72,73,75-81]. Endothelial alignment is critical for both EPCs and mature ECs to maintain vascular homeostasis in response to shear stress [51,56-62,82-89]. Unidirectional laminar flow, characterized by high shear stress and the synchronous performance of shear stress and cyclic strain, induces EC elongation and alignment in the flow direction, with the subsequent generation of tight junctions between ECs and the eventual formation of a confluent EC monolayer [51,56-62,82-91]. Further, laminar flow governs cell turnover and vascular tone, which regulate vascular permeability and sustain an anti-inflammatory microenvironment [51,64,72,82-86,92]. Mechanistically, the atheroprotective effect of unidirectional laminar flow was recently found to be largely determined by the decreased activity of Hippo pathway members Yes-associated protein (YAP) and transcriptional coactivator with PDZ-binding motif (TAZ) in ECs that suppress c-Jun N-terminal kinase (JNK) signaling and downregulate the expression of pro-inflammatory genes [93-95]. In contrast, turbulent, multidirectional, oscillatory flows are notable for their pathological low shear stress, asynchronous shear stress action, and cyclic strain on the vascular wall [82-86,90,91]. They disrupt 
EC alignment, result in the acquisition of round or polymorphic shapes by ECs, accelerate their apoptosis, impair the regulation of vascular tone and permeability, and stimulate a pro-inflammatory microenvironment [82-86]. Disturbed flow was shown to elicit a proatherogenic response through upregulation of the pro-inflammatory transcription factor nuclear factor $\kappa \beta(\mathrm{NF}-\kappa \beta)[91,96]$ and an inhibition of the atheroprotective factor Kruppel-like factor 2 (KLF2) [96] and the antioxidant factor nuclear factor (erythroid-derived 2)-like 2 (Nrf2) at the DNA binding step [96,97].

However, studies on the mechanobiology of EPCs are mostly limited to classical molecular biology techniques and therefore explore only a minor percentage of relevant biochemical pathways. Furthermore, cell signaling networks are characterized by a considerable redundancy in master regulator molecules that exert pleiotropic effects on different molecular pathways. The combination of high-throughput methods (e.g., whole-transcriptome sequencing, or protein arrays such as dot blot) and routine molecular biology techniques (e.g., quantitative polymerase chain reaction (qPCR) or conventional Western blotting) is capable of determining the activity of numerous biochemical pathways simultaneously. Although expensive, this approach provides a large amount of data drawn from high-throughput techniques, which are then validated through the use of classical methods. In addition, one can highlight a synergistic combination of whole-transcriptome sequencing and laser capture microdissection, which is a technique designed for the isolation of specific cells or tissues at a microscopic (even at a single-cell) resolution that enables high-throughput analysis of the genomic data from a source/region of interest. In this review, we focus on whole-transcriptome sequencing, as it combines transparent and efficient data processing with large data output, relatively low costs, and simple verification by qPCR.

Currently, there are two main approaches to the analysis of the whole transcriptome: whole-transcriptome shotgun sequencing (RNA sequencing, RNA-seq), and whole-transcriptome, target/tag sequencing, with or without restriction digestion [98-100]. The former enables the characterization of both mRNA and non-coding RNA, regardless of polyadenylation, while the latter exclusively targets mRNA, i.e., all polyadenylated transcripts within the transcriptome [98-100]. To improve the identification of low-abundance transcripts, an increase in the depth of the sequencing can be accomplished by removing irrelevant RNAs. The enrichment of the relevant part of the transcriptome prior to sequencing is achieved by rRNA depletion (e.g., utilizing biotin-streptavidin-based bead systems) or the selection of poly-A tailed transcripts from total RNA (e.g., using the Oligo dT magnetic bead system) when employing whole-transcriptome shotgun sequencing or whole-transcriptome target/tag sequencing, respectively. Generally, whole-transcriptome shotgun sequencing is characterized by a higher output but is more expensive compared to whole-transcriptome target/tag sequencing. Therefore, the choice between these two techniques is unique to each particular experiment. We further present demonstrative examples of how whole-transcriptome sequencing can be used in endothelial mechanobiology and vascular tissue engineering studies.

\section{Application of Whole-Transcriptome Sequencing to Endothelial Mechanobiology Studies}

Whole-transcriptome sequencing has been widely utilized to investigate the response of various EC cultures to different types of shear stress, of variable intensity and at sequential time points, as well as to the addition of bioactive molecules. A number of milestone papers employed this approach to discover specific patterns of gene expression under the abovementioned conditions. The genome-wide expression profiling of human umbilical vein ECs (HUVECs) exposed to unidirectional laminar shear stress (from $24 \mathrm{~h}$ up to six days of culture) identified three clusters of gene response: (1) downregulated by the shear stress but unaffected by the tumor necrosis factor (TNF)- $\alpha$; $(2)$ upregulated by the TNF- $\alpha$ treatment both under static and shear conditions; and (3) upregulated by the shear stress but downregulated or unchanged after the TNF- $\alpha$ exposure [101].

In HUVECs cultured under prolonged (six days) pulsatile flow in comparison with static conditions, the gene expression of a potent vasoconstrictor endothelin-1 (EDN1) was downregulated while that of the pro-thrombotic molecule plasminogen activator inhibitor 1 (PAI1) remained 
unchanged [101]. In contrast, the expression of KLF2, NOS3, and THBD genes encoding KLF2, endothelial nitric oxide synthase, and thrombomodulin-all of which are anti-thrombotic or anti-atherosclerotic molecules-was significantly higher in sheared than in statically cultured ECs [101]. In addition, exposure to the shear stress also suppressed the expression of pro-inflammatory SELE, VCAM1, CCL2, CX3CL1, CXCL6, and CXCL8 genes encoding E-selectin, vascular cell adhesion molecule 1, C-C motif ligand 2 (monocyte chemoattractant protein 1), C-X3-C motif ligand 1 (fractalkine), C-X-C motif ligand 6 (granulocyte chemotactic protein 2), and interleukin-8, respectively [101,102]. Such a pattern of gene expression regulated by shear stress was induced through the KLF2-mediated inhibition of the nuclear activity of activating transcription factor 2 (ATF2), the regulation of SMAD/activator protein-1 (AP-1) axis, and the involvement of the Nrf2 that binds the antioxidant response element (ARE) [101]. A follow-up study by the same research group confirmed the upregulation of both KLF2- and Nrf2-induced transcriptomes by shear stress [103]. Highlighting the importance of KLF2 in maintaining endothelial homeostasis, its molecular inducers such as statins [104], resveratrol [105], suberanilohydroxamic acid [106] and tannic acid [107] were recently suggested as a potential therapy for atherosclerosis treatment and prophylaxis.

Another study that employed genome-wide expression profiling identified 32 genes up- or downregulated in HUVECs upon $24 \mathrm{~h}$ of exposure to high shear stress compared to low shear stress [108]. Genes for C-X-C chemokine receptor type 4 (CXCR4), caspase recruitment domain-8 (CARD8) and apoptosis-associated protein 2 (THPA2)—which are mediators of inflammation and apoptosis-were under-expressed at high shear in comparison with low shear stress, however, the reverse effect was observed for tumor necrosis factor $\alpha$-induced protein 3 (TNFAIP3), which is an inhibitor of the cytokine-induced activation of NF-kB in ECs [108]. The gene expression of the acyl-CoA synthetase family member 3 (ACSL3), which activates long-chain fatty acids and therefore enhances the synthesis of cellular lipids, was lowered at high shear stress, in keeping with its atheroprotective role [108]. As defined by RNA sequencing, the exposure of HUVEC cultures to a high laminar shear stress for $72 \mathrm{~h}$ also decreased the expression of genes responsible for glycolysis and intimal acidification, including those encoding hexokinase (HK1/2), phosphofructokinase (PFK1), and 6-phosphofructo-2-kinase/fructose-2,6-biphosphatase (PFKFB3) in a KLF2-dependent manner [109].

Further, whole-transcriptome sequencing can be applied to study the impact of gene knockdown (e.g., by means of small interfering RNA (siRNA) or short hairpin RNA (shRNA)) or gene overexpression (e.g., using adenoviral or lentiviral transfection) on the global gene expression in ECs. For instance, Maleszewska et al. showed that the knockdown of EZH2, a major methyltransferase in the Polycomb repressive complex-2, which methylates histone $\mathrm{H} 3$ at lysine-27 and therefore controls gene expression [110], increased the expression of 2042 genes, particularly those responsible for cell adhesion, and reduced the expression of 2654 genes, primarily those governing the cell cycle (e.g., CCNA1, CCNB1, and CCNB2) in HUVECs exposed to the high shear stress for $72 \mathrm{~h}$ [111]. Similarly, KLF4 gene overexpression enhanced biosynthesis of the nitric oxide and upregulated cholesterol efflux and oxidation while downregulating cholesterol synthesis and mitigating inflammation in HUVECs, largely via transactivation of cholesterol-25-hydroxylase, an enzyme converting cholesterol to 25-hydroxycholesterol, and liver $\mathrm{X}$ receptor, a transcription factor regulating cholesterol synthesis and metabolism [112].

As human ECs isolated from distinct vascular regions are characterized by significant diversity, and both atherosclerosis and vascular grafting involve arteries, arterial ECs are preferable to HUVECs as a model for studying endothelial mechanobiology [113]. Compared to primary human coronary artery ECs (HCAECs) cultured under high unidirectional laminar shear stress for $24 \mathrm{~h}, 8177$ (50\%) and $9369(57 \%)$ of genes were differentially expressed in HCAECs cultured for the same time under either bidirectional oscillatory shear stress or static conditions, respectively [114]. However, only 1618 $(10 \%)$ of genes were differentially expressed in cells cultured under bidirectional oscillatory shear stress and under static conditions [114]. For cells cultured under any of the three abovementioned 
conditions, the fold change in the expression level obtained using qPCR was similar to that obtained using RNA sequencing for the following core shear-sensitive genes: KLF2, angiopoietin-2 (ANGPT2), NOS3, VCAM1, CXCR4, inhibitor of DNA binding 1 (ID1), fatty acid binding protein 4 (FABP4), hyaluronoglucosaminidase 2 (HYAL2), KLF11, serpin peptidase inhibitor member 2 (SERPINE2), LIM domain 7 (LMO7), chemokine (C-C motif) ligand 14 (CCL14), TEK tyrosine kinase (TEK), latexin (LXN), chromosome 10 open reading frame 10 (C10orf10), and ephrin A1 (EFNA1) [114]. The majority of genes that were differentially expressed under static conditions versus laminar shear stress $(77 \%)$ and laminar versus oscillatory shear stress $(88 \%)$ were overlapped and indicative of the existence of similar gene expression patterns in cells cultured under static conditions and at oscillatory shear stress; this was also confirmed by qPCR [114].

In addition to arterial and vein ECs, whole-transcriptome sequencing has been used for the investigation of shear stress effects on the global gene expression of endocardial ECs (EECs). An analysis of distinct regions within the porcine left ventricle showed that the number of differentially expressed genes in apex-mid-ventricle, base-mid-ventricle, and base-apex comparisons was 0, 325, and 1051, respectively. These differences in gene expression patterns were consistent with those in shear stress values between the regions $[115,116]$. Notable discrepancies between base and apex were detected regarding the increased expression of TFPI (tissue factor pathway inhibitor) and PTGIS (prostacyclin synthase) genes, which encode two major anticoagulant proteins, in the apex EECs intrinsically exposed to low shear stress $[115,116]$. Furthermore, HS6ST2 and NRP1 genes encoding the components of glycocalyx, which provides electrical repulsion of activated platelets [117], were upregulated in the apex compared to the base $[115,116]$. A pathway analysis found apical upregulation of the genes responsible for translation initiation and oxidative phosphorylation [115,116]. This can reflect a physiological response of the apex EECs to avoid excessive coagulation and thrombosis.

Another important issue is the temporal variation in the gene expression profile in ECs under shear stress. Time-resolved RNA sequencing of HUVECs exposed to laminar or oscillatory shear conditions revealed a significant number of differentially expressed genes at ten time points during $24 \mathrm{~h} \mathrm{[118].} \mathrm{The} \mathrm{expression} \mathrm{of} \mathrm{genes} \mathrm{governing} \mathrm{cell} \mathrm{cycle} \mathrm{(e.g.,} \mathrm{those} \mathrm{responsible} \mathrm{for} \mathrm{the} \mathrm{G1/S} \mathrm{transition)}$ commenced to differ between four and six hours after the initial exposure to shear, being substantially higher at the oscillatory flow [118]. In keeping with these findings, a notable upregulation of gene pathways responsible for ribosomal production and activity as well as for global protein expression and degradation was observed at later time points [118]. Genes related to the production of reactive oxygen species were overexpressed as early as hour two, while those encoding certain antioxidative enzymes, such as catalase, glucose-6-phosphate dehydrogenase, or $\mathrm{NAD}(\mathrm{P}) \mathrm{H}$ dehydrogenase (quinone) 1 were downregulated at hour nine to hour twelve [118]. However, genes for mitochondrial superoxide dismutase and metallothioneins were overexpressed at hours four and nine, respectively, while those for peroxiredoxins and glutathione peroxidases were upregulated from hour twenty [118]. Consistent with the current understanding of mechanotransduction and atherosclerosis [82-86], the expression of the pro-inflammatory genes (e.g., NFKB1, VCAM1, SELE, CCL2, and CXCL8) was significantly increased in the ECs between hours two and six [118]. Oscillatory shear stress was associated with the endothelial-to-mesenchymal transition expression pattern (downregulation of endothelial marker genes CD34, von Willebrand factor (VWF), and NOS3 from hour six, along with the upregulation of mesenchymal marker genes cadherin-2 (CDH2), fibulin-5 (FBLN5), and tropomyosin $\alpha-1$ chain (TPM1) from hour twelve) [118]. Expression of the HIF1A gene-encoding, hypoxia-inducible factor was elevated from hour four [118], in concert with the crucial role of hypoxia in the development of atherosclerosis [119]. The application of whole-transcriptome sequencing in endothelial mechanobiology has not been limited to the identification of mechanosensitive genes, but was also extended to the determination of the flow-regulated, long, non-coding RNAs (lncRNAs) constituting a large part of the transcriptome [105]. For instance, LINC00341, an abundant lncRNA that has a sequence verified by qPCR and is markedly expressed under pulsatile shear conditions, has 
been shown to suppress TNF- $\alpha$-induced vascular cell adhesion molecule (VCAM)- 1 expression and monocyte adhesion [120].

Regarding translational medicine, whole-transcriptome sequencing has proved useful in the implementation of patient-oriented approaches in cardiovascular medicine, i.e., for the transfer of the patient's data to the bench to uncover a molecular basis for corresponding diseases. By using 3D-computational tomography angiography (3D-CTA) and by calculating the shear stress in three patients with unruptured intracranial aneurysms and different arterial geometries, Aoki et al. obtained shear stress values and flow type (low shear stress at either laminar or turbulent flow and high shear stress at the laminar flow) in primary cultures of human carotid artery ECs (HCtAECs) [102]. Subsequent RNA sequencing, verified by qPCR, identified that the transcriptomic signatures associated with nucleosome assembly, mitotic cell cycle, DNA replication, and the recruiting/adhesion of immune cells tend to be overrepresented in cells cultured at low shear stress, in particular under turbulent flow conditions, when compared to those cultured at high shear stress [102]. This corresponds to seminal findings that demonstrate that the accelerated turnover of ECs $[121,122]$ and considerable inflammation [123] occur in regions of turbulent flow.

Cyclic strain, also called cyclic stretch, is another major hemodynamic force affecting the differentiation of EPCs and the gene expression profile of mature ECs in the human body [124-128]. The genome-wide miRNA microarray analysis of HUVECs subjected to the cyclic strain for $24 \mathrm{~h}$ (60 cycles/minute) detected 20 upregulated and 18 downregulated miRNAs when compared to statically cultured cells [129]. These miRNAs were involved in numerous signaling pathways, including those regulating apoptosis, cell cycle control, differentiation, and inflammation [129]. Similar results were obtained in the genome-wide analysis of miRNAs in HUVECs exposed to the cyclic strain for three hours (60 cycles/minute) [130].

\section{Application of Whole-Transcriptome Sequencing to Vascular Tissue Engineering Studies}

Unfortunately, there have been few attempts to utilize whole-transcriptome sequencing to evaluate the response of ECs on their attachment to tubular grafts. However, even biocompatible polymers, such as extracellular matrix proteins, showed considerable variation in their ability to enhance EPC adhesion and further differentiation under shear stress conditions [69,131]. Compared to type I collagen and laminin, fibronectin better promotes the differentiation of EPCs, possibly because of its profound stimulative effects on the shear stress-related expression of integrins $[69,131]$. Integrin-mediated signaling is required to activate the paxillin/focal adhesion kinase (FAK)/rat sarcoma (RAS)/extracellular signal-regulated kinase (ERK) pathway and induce endothelial lineage differentiation $[69,131]$.

The micro- and nanopatterning of polymer surfaces has been suggested as a promising approach that increases biocompatibility and therefore improves cell attachment [132,133]. A genome-wide expression analysis found that 3303 genes were significantly underexpressed, while 905 genes were substantially overexpressed in primary human dermal microvascular ECs (HDMECs) cultured on micropatterned polydimethylsiloxane (PDMS) substrates, when compared to their non-patterned counterparts [134]. In particular, a notable upregulation of RNA processing, DNA replication, and DNA repair pathways in HDMECs on the micropatterned substrates was noted, indicating their accelerated proliferation [134]. Genes responsible for extracellular matrix degradation and vascular remodeling (e.g., those encoding matrix metalloproteinase 1 (MMP1) and 16 (MMP16)) were also overexpressed on micropatterned surfaces [134]. Among the downregulated pathways were transmembrane receptor activity, G-protein-coupled receptor activity, and ion channel activity [134].

In 2006, Takahashi and Yamanaka demonstrated that four transcription factors (c-Myc, Oct4, Sox2, and Klf4) are responsible for transforming adult fibroblasts into induced pluripotent stem cells (iPSCs) that exhibit a similar morphology, proliferation pattern, gene expression profile, and surface markers to embryonic stem cells $[135,136]$. The iPSCs showed an almost inexhaustible capacity for replication and were able to differentiate into cell types of all three germ layers $[135,136]$. Subsequent studies confirmed 
these findings, paving the way for the investigation of iPSC applications in various biomedical fields [137-139]. As the use of iPSCs does not involve ethical considerations, these cells have been suggested as a promising tool for tissue engineering and regenerative medicine. For instance, iPSCs can be differentiated into ECs [140], vascular smooth muscle cells [140], and cardiomyocytes [140,141]. This feature of iPSCs was successfully applied in the generation of autologous ECs [142] and smooth muscle cells [142-144] to seed tissue-engineered vascular grafts. Recent studies revealed that immature iPSC-ECs can be differentiated into mature arterial ECs in as early as $24 \mathrm{~h}$ using a biomimetic flow bioreactor [145] and will acquire a physiological phenotype under shear stress conditions [146,147]. As iPSC-derived ECs adequately respond to growth factors, inflammatory and thrombotic stimuli, and hemodynamic forces, they were proposed as a perfect functional lining for bioartificial blood vessels [148,149]. Furthermore, iPSC-ECs cultured along with fibroblasts form $2 \mathrm{D}$ and 3D capillary networks are potentially capable of facilitating perfusion of non-vascular, tissue-engineered constructs [148-152]. One can apply such 3D models to the study of endothelial mechanobiology under pulsatile flow conditions and mimic the anatomy of different vessels, resulting in a simulation where laminar or turbulent flow pattern occurs. This can be realized utilizing microfluidic devices for microvascular research, or conventional bioreactors to imitate the hemodynamics of small to large arteries. The latter approach often requires the use of polymer scaffolds. Whole-transcriptome sequencing can additionally improve such experimentation, permitting a demarcation of endothelial differentiation stages with genome-wide coverage and simultaneous detection of molecular responses across multiple pathways at sequential time points.

\section{Conclusions and Future Directions}

In recent years, a number of studies have demonstrated the advantage of utilizing whole-transcriptome sequencing in endothelial mechanobiology and vascular tissue engineering. Such an approach can be successfully applied to any cell line or tissue regardless of experimental conditions, with the RNA yield and quality of the extraction sample being the only limiting factors. Moreover, RNA amplification is capable of maximizing the amount of RNA needed for subsequent sequencing or reverse transcription. As discussed above, whole-transcriptome sequencing can be employed for: 1) routine global gene expression profiling of ECs cultured with various biomechanical cues; 2 ) deep investigation of endothelial responses to physiological changes, such as the addition of bioactive factors; 3 ) deciphering spatiotemporal variation in the expression of multiple signaling pathways; 4) testing patient-specific biophysical conditions on EC cultures; and 5) determining transcriptomic signatures in ECs during their culture on distinct polymer surfaces. A scheme illustrating the use of whole-transcriptome sequencing in studying endothelial response to shear stress is depicted in Figure 1.

It is also important to note that the microarray/RNA-seq data generated in different studies are deposited in publicly available databases. This allows researchers to mine gene profiling data in order to perform various in silico analyses of the transcriptome. Examples of basic bioinformatics analyses of such published datasets were recently described by $\mathrm{Xu}$ [153].

There are still gaps in our knowledge of the gene expression patterns in certain arterial cells in response to shear stress, cyclic strain, or both combined. Another level of complexity is the analysis of the mentioned expression profiles in different segments of the arterial tree, which often require laser capture microdissection in order to isolate regions of interest. The proper engineering of biodegradable vascular grafts must include tracing global gene expression in the newly formed tissue. In addition, transcriptomic profiling can significantly extend our understanding of EPC maturation once they are attached to distinct polymers (e.g., extracellular matrix proteins). To improve upon the respective experiments, whole-transcriptome sequencing must be combined with qPCR and protein expression should be measured using routine molecular biology methods or proteomics techniques. 


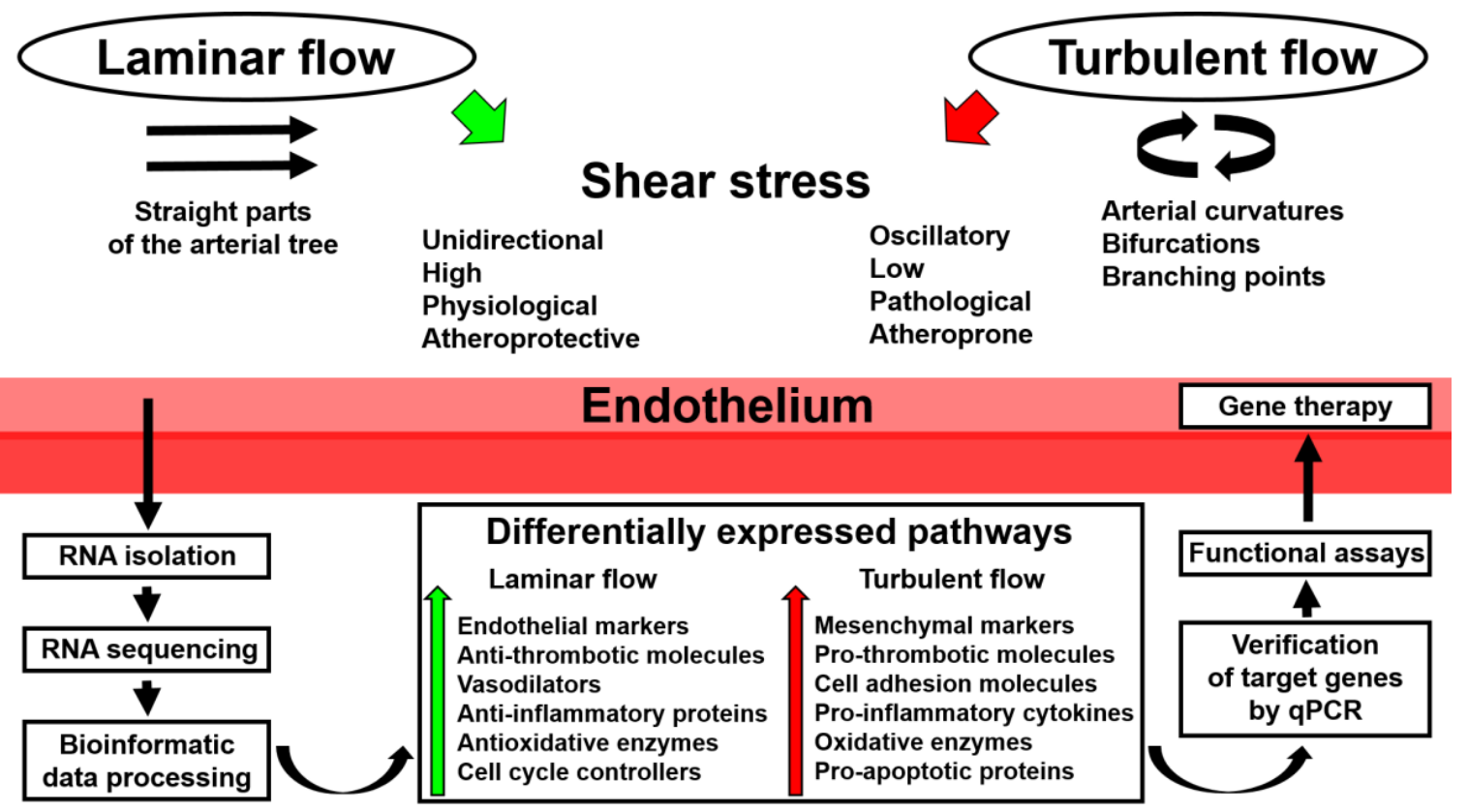

Figure 1. Application of whole-transcriptome sequencing in endothelial mechanobiology. qPCR: quantitative polymerase chain reaction.

With the growing amount of cardiovascular research using whole-transcriptome sequencing, researchers are now able to perform an in silico analysis of gene expression responses to various biophysical stimuli in ECs from different sources. Such an approach can be useful when comparing site-specific physiological features and can provide further insight into the origin of vascular diseases. To summarize, whole-transcriptome sequencing is currently recognized as a versatile tool in physiological genomics and can be broadly implemented in various branches of vascular biology.

Acknowledgments: This study was funded by Russian Science Foundation (grant No 17-75-20004 “Development of personalized tissue-engineered, small-diameter vascular graft in vitro under pulsatile flow conditions").

Conflicts of Interest: The authors declare no conflict of interest. The founding sponsors had no role in the writing of the manuscript.

\section{References}

1. GBD 2016 Causes of Death Collaborators. Global, regional, and national age-sex specific mortality for 264 causes of death, 1980-2016: A systematic analysis for the Global Burden of Disease Study 2016. Lancet 2017, 390, 1151-1210. [CrossRef] [PubMed]

2. GBD 2016 DALYs and HALE Collaborators. Global, regional, and national disability-adjusted life-years (DALYs) for 333 diseases and injuries and healthy life expectancy (HALE) for 195 countries and territories, 1990-2016: A systematic analysis for the Global Burden of Disease Study 2016. Lancet 2017, 390, 1260-1344. [CrossRef] [PubMed]

3. Friedman, A.A.; Letai, A.; Fisher, D.E.; Flaherty, K.T. Precision medicine for cancer with next-generation functional diagnostics. Nat. Rev. Cancer 2015, 15, 747-756. [CrossRef] [PubMed]

4. Pauli, C.; Hopkins, B.D.; Prandi, D.; Shaw, R.; Fedrizzi, T.; Sboner, A.; Sailer, V.; Augello, M.; Puca, L.; Rosati, R.; et al. Personalized in vitro and in vivo cancer models to guide precision medicine. Cancer Discov. 2017, 7, 462-477. [CrossRef] [PubMed]

5. Dimitrakopoulos, L.; Prassas, I.; Diamandis, E.P.; Charames, G.S. Onco-proteogenomics: Multi-omics level data integration for accurate phenotype prediction. Crit. Rev. Clin. Lab. Sci. 2017, 54, 414-432. [CrossRef] [PubMed]

6. Laurila, P.P.; Surakka, I.; Sarin, A.P.; Yetukuri, L.; Hyötyläinen, T.; Söderlund, S.; Naukkarinen, J.; Tang, J.; Kettunen, J.; Mirel, D.B.; et al. Genomic, transcriptomic, and lipidomic profiling highlights the role of 
inflammation in individuals with low high-density lipoprotein cholesterol. Arterioscler. Thromb. Vasc. Biol. 2013, 33, 847-857. [CrossRef] [PubMed]

7. Würtz, P.; Raiko, J.R.; Magnussen, C.G.; Soininen, P.; Kangas, A.J.; Tynkkynen, T.; Thomson, R.; Laatikainen, R.; Savolainen, M.J.; Laurikka, J.; et al. High-throughput quantification of circulating metabolites improves prediction of subclinical atherosclerosis. Eur. Heart J. 2012, 33, 2307-2316. [CrossRef] [PubMed]

8. Döring, Y.; Noels, H.; Weber, C. The use of high-throughput technologies to investigate vascular inflammation and atherosclerosis. Arterioscler. Thromb. Vasc. Biol. 2012, 32, 182-195. [CrossRef] [PubMed]

9. Qiao, D.; Lange, C.; Beaty, T.H.; Crapo, J.D.; Barnes, K.C.; Bamshad, M.; Hersh, C.P.; Morrow, J.; Pinto-Plata, V.M.; Marchetti, N.; et al. Exome sequencing analysis in severe, early-onset chronic obstructive pulmonary disease. Am. J. Respir. Crit. Care Med. 2016, 193, 1353-1363. [CrossRef] [PubMed]

10. Khurana, R.; Ranches, G.; Schafferer, S.; Lukasser, M.; Rudnicki, M.; Mayer, G.; Hüttenhofer, A. Identification of urinary exosomal noncoding RNAs as novel biomarkers in chronic kidney disease. RNA 2017, 23, 142-152. [CrossRef] [PubMed]

11. Kalim, S.; Rhee, E.P. An overview of renal metabolomics. Kidney Int. 2017, 91, 61-69. [CrossRef] [PubMed]

12. Vivante, A.; Hildebrandt, F. Exploring the genetic basis of early-onset chronic kidney disease. Nat. Rev. Nephrol. 2016, 12, 133-146. [CrossRef] [PubMed]

13. Ju, W.; Greene, C.S.; Eichinger, F.; Nair, V.; Hodgin, J.B.; Bitzer, M.; Lee, Y.S.; Zhu, Q.; Kehata, M.; Li, M.; et al. Defining cell-type specificity at the transcriptional level in human disease. Genome Res. 2013, 23, 1862-1873. [CrossRef] [PubMed]

14. Guasch-Ferré, M.; Hruby, A.; Toledo, E.; Clish, C.B.; Martínez-González, M.A.; Salas-Salvadó, J.; Hu, F.B. Metabolomics in prediabetes and diabetes: A systematic review and meta-analysis. Diabetes Care 2016, 39, 833-846. [CrossRef] [PubMed]

15. De Bruin, C.; Dauber, A. Insights from exome sequencing for endocrine disorders. Nat. Rev. Endocrinol. 2015, 11, 455-464. [CrossRef] [PubMed]

16. Wahl, S.; Drong, A.; Lehne, B.; Loh, M.; Scott, W.R.; Kunze, S.; Tsai, P.C.; Ried, J.S.; Zhang, W.; Yang, Y.; et al. Epigenome-wide association study of body mass index, and the adverse outcomes of adiposity. Nature 2017, 541, 81-86. [CrossRef] [PubMed]

17. Johar, A.S.; Anaya, J.M.; Andrews, D.; Patel, H.R.; Field, M.; Goodnow, C.; Arcos-Burgos, M. Candidate gene discovery in autoimmunity by using extreme phenotypes, next generation sequencing and whole exome capture. Autoimmun. Rev. 2015, 14, 204-209. [CrossRef] [PubMed]

18. Norman, P.J.; Hollenbach, J.A.; Nemat-Gorgani, N.; Marin, W.M.; Norberg, S.J.; Ashouri, E.; Jayaraman, J.; Wroblewski, E.E.; Trowsdale, J.; Rajalingam, R.; et al. Defining KIR and HLA Class I genotypes at highest resolution via high-throughput sequencing. Am. J. Hum. Genet. 2016, 99, 375-391. [CrossRef] [PubMed]

19. Parikshak, N.N.; Gandal, M.J.; Geschwind, D.H. Systems biology and gene networks in neurodevelopmental and neurodegenerative disorders. Nat. Rev. Genet. 2015, 16, 441-458. [CrossRef] [PubMed]

20. Chen-Plotkin, A.S. Unbiased approaches to biomarker discovery in neurodegenerative diseases. Neuron 2014, 84, 594-607. [CrossRef] [PubMed]

21. Jansen, I.E.; Ye, H.; Heetveld, S.; Lechler, M.C.; Michels, H.; Seinstra, R.I.; Lubbe, S.J.; Drouet, V.; Lesage, S.; Majounie, E.; et al. Discovery and functional prioritization of Parkinson's disease candidate genes from large-scale whole exome sequencing. Genome Biol. 2017, 18, 22. [CrossRef] [PubMed]

22. Berg, E.L. Systems biology in drug discovery and development. Drug Discov. Today 2014, 19, 113-125. [CrossRef] [PubMed]

23. De Chassey, B.; Meyniel-Schicklin, L.; Vonderscher, J.; André, P.; Lotteau, V. Virus-host interactomics: New insights and opportunities for antiviral drug discovery. Genome Med. 2014, 6, 115. [CrossRef] [PubMed]

24. O'Reilly, L.P.; Long, O.S.; Cobanoglu, M.C.; Benson, J.A.; Luke, C.J.; Miedel, M.T.; Hale, P.; Perlmutter, D.H.; Bahar, I.; Silverman, G.A.; et al. A genome-wide RNAi screen identifies potential drug targets in a C. elegans model of $\alpha 1$-antitrypsin deficiency. Hum. Mol. Genet. 2014, 23, 5123-5132. [CrossRef] [PubMed]

25. Wang, R.S.; Maron, B.A.; Loscalzo, J. Systems medicine: Evolution of systems biology from bench to bedside. Wiley Interdiscip. Rev. Syst. Biol. Med. 2015, 7, 141-161. [CrossRef] [PubMed]

26. Woo, J.H.; Shimoni, Y.; Yang, W.S.; Subramaniam, P.; Iyer, A.; Nicoletti, P.; Rodríguez Martínez, M.; López, G.; Mattioli, M.; Realubit, R.; et al. Elucidating compound mechanism of action by network perturbation analysis. Cell 2015, 162, 441-451. [CrossRef] [PubMed] 
27. Backus, K.M.; Correia, B.E.; Lum, K.M.; Forli, S.; Horning, B.D.; González-Páez, G.E.; Chatterjee, S.; Lanning, B.R.; Teijaro, J.R.; Olson, A.J.; et al. Proteome-wide covalent ligand discovery in native biological systems. Nature 2016, 534, 570-574. [CrossRef] [PubMed]

28. Lapek, J.D., Jr.; Greninger, P.; Morris, R.; Amzallag, A.; Pruteanu-Malinici, I.; Benes, C.H.; Haas, W. Detection of dysregulated protein-association networks by high-throughput proteomics predicts cancer vulnerabilities. Nat. Biotechnol. 2017, 35, 983-989. [CrossRef] [PubMed]

29. Bush, E.C.; Ray, F.; Alvarez, M.J.; Realubit, R.; Li, H.; Karan, C.; Califano, A.; Sims, P.A. PLATE-Seq for genome-wide regulatory network analysis of high-throughput screens. Nat. Commun. 2017, 8, 105. [CrossRef] [PubMed]

30. Zampieri, M.; Sekar, K.; Zamboni, N.; Sauer, U. Frontiers of high-throughput metabolomics. Curr. Opin. Chem. Biol. 2017, 36, 15-23. [CrossRef] [PubMed]

31. Palumbo, V.D.; Bruno, A.; Tomasello, G.; Damiano, G.; Lo Monte, A.I. Bioengineered vascular scaffolds: The state of the art. Int. J. Artif. Organs 2014, 37, 503-512. [CrossRef] [PubMed]

32. Rocco, K.A.; Maxfield, M.W.; Best, C.A.; Dean, E.W.; Breuer, C.K. In vivo applications of electrospun tissue-engineered vascular grafts: A review. Tissue Eng. Part B Rev. 2014, 20, 628-640. [CrossRef] [PubMed]

33. Chong, D.S.; Lindsey, B.; Dalby, M.J.; Gadegaard, N.; Seifalian, A.M.; Hamilton, G. Luminal surface engineering, 'micro and nanopatterning': Potential for self endothelialising vascular grafts? Eur. J. Vasc. Endovasc. Surg. 2014, 47, 566-576. [CrossRef] [PubMed]

34. Niu, G.; Sapoznik, E.; Soker, S. Bioengineered blood vessels. Expert Opin. Biol. Ther. 2014, 14, $403-410$. [CrossRef] [PubMed]

35. Ren, X.; Feng, Y.; Guo, J.; Wang, H.; Li, Q.; Yang, J.; Hao, X.; Lv, J.; Ma, N.; Li, W. Surface modification and endothelialization of biomaterials as potential scaffolds for vascular tissue engineering applications. Chem. Soc. Rev. 2015, 44, 5680-5742. [CrossRef] [PubMed]

36. Tara, S.; Rocco, K.A.; Hibino, N.; Sugiura, T.; Kurobe, H.; Breuer, C.K.; Shinoka, T. Vessel bioengineering. Circ. J. 2014, 78, 12-19. [CrossRef] [PubMed]

37. Yang, J.Y.; Sarwal, M.M. Transplant genetics and genomics. Nat. Rev. Genet. 2017, 18, 309-326. [CrossRef] [PubMed]

38. Rehm, H.L. Evolving health care through personal genomics. Nat. Rev. Genet. 2017, 18, 259-267. [CrossRef] [PubMed]

39. Nelson, M.R.; Johnson, T.; Warren, L.; Hughes, A.R.; Chissoe, S.L.; Xu, C.F.; Waterworth, D.M. The genetics of drug efficacy: Opportunities and challenges. Nat. Rev. Genet. 2016, 17, 197-206. [CrossRef] [PubMed]

40. Willis, J.C.; Lord, G.M. Immune biomarkers: The promises and pitfalls of personalized medicine. Nat. Rev. Immunol. 2015, 15, 323-329. [CrossRef] [PubMed]

41. DeVita, V.T., Jr.; Eggermont, A.M.; Hellman, S.; Kerr, D.J. Clinical cancer research: The past, present and the future. Nat. Rev. Clin. Oncol. 2014, 11, 663-669. [CrossRef] [PubMed]

42. André, N.; Carré, M.; Pasquier, E. Metronomics: Towards personalized chemotherapy? Nat. Rev. Clin. Oncol. 2014, 11, 413-431. [CrossRef] [PubMed]

43. Schilsky, R.L. Implementing personalized cancer care. Nat. Rev. Clin. Oncol. 2014, 11, 432-438. [CrossRef] [PubMed]

44. Völzke, H.; Schmidt, C.O.; Baumeister, S.E.; Ittermann, T.; Fung, G.; Krafczyk-Korth, J.; Hoffmann, W.; Schwab, M.; Meyer zu Schwabedissen, H.E.; Dörr, M.; et al. Personalized cardiovascular medicine: Concepts and methodological considerations. Nat. Rev. Cardiol. 2013, 10, 308-316. [CrossRef] [PubMed]

45. Shantsila, E.; Watson, T.; Lip, G.Y. Endothelial progenitor cells in cardiovascular disorders. J. Am. Coll. Cardiol. 2007, 49, 741-752. [CrossRef] [PubMed]

46. Liu, T.; Liu, S.; Zhang, K.; Chen, J.; Huang, N. Endothelialization of implanted cardiovascular biomaterial surfaces: The development from in vitro to in vivo. J. Biomed. Mater. Res. A 2014, 102, 3754-3772. [CrossRef] [PubMed]

47. Melchiorri, A.J.; Bracaglia, L.G.; Kimerer, L.K.; Hibino, N.; Fisher, J.P. In Vitro endothelialization of biodegradable vascular grafts via endothelial progenitor cell seeding and maturation in a tubular perfusion system bioreactor. Tissue Eng. Part C Methods 2016, 22, 663-670. [CrossRef] [PubMed]

48. Ranjan, A.K.; Kumar, U.; Hardikar, A.A.; Poddar, P.; Nair, P.D.; Hardikar, A.A. Human blood vessel-derived endothelial progenitors for endothelialization of small diameter vascular prosthesis. PLoS ONE 2009, 4, e7718. [CrossRef] [PubMed] 
49. Ingram, D.A.; Mead, L.E.; Tanaka, H.; Meade, V.; Fenoglio, A.; Mortell, K.; Pollok, K.; Ferkowicz, M.J.; Gilley, D.; Yoder, M.C. Identification of a novel hierarchy of endothelial progenitor cells using human peripheral and umbilical cord blood. Blood 2004, 104, 2752-2760. [CrossRef] [PubMed]

50. Hill, J.M.; Zalos, G.; Halcox, J.P.; Schenke, W.H.; Waclawiw, M.A.; Quyyumi, A.A.; Finkel, T. Circulating endothelial progenitor cells, vascular function, and cardiovascular risk. N. Engl. J. Med. 2003, 348, 593-600. [CrossRef] [PubMed]

51. Yamamoto, K.; Takahashi, T.; Asahara, T.; Ohura, N.; Sokabe, T.; Kamiya, A.; Ando, J. Proliferation, differentiation, and tube formation by endothelial progenitor cells in response to shear stress. J. Appl. Physiol. 2003, 95, 2081-2088. [CrossRef] [PubMed]

52. Yoder, M.C. Human endothelial progenitor cells. Cold. Spring. Harb. Perspect. Med. 2012, 2 , a006692. [CrossRef] [PubMed]

53. Asahara, T.; Murohara, T.; Sullivan, A.; Silver, M.; van der Zee, R.; Li, T.; Witzenbichler, B.; Schatteman, G.; Isner, J.M. Isolation of putative progenitor endothelial cells for angiogenesis. Science 1997, 275, 964-967. [CrossRef] [PubMed]

54. Boyer, M.; Townsend, L.E.; Vogel, L.M.; Falk, J.; Reitz-Vick, D.; Trevor, K.T.; Villalba, M.; Bendick, P.J.; Glover, J.L. Isolation of endothelial cells and their progenitor cells from human peripheral blood. J. Vasc. Surg. 2000, 31, 181-189. [CrossRef] [PubMed]

55. Peters, E.B. Endothelial progenitor cells for the vascularization of engineered tissues. Tissue Eng. Part. B Rev. 2018, 24, 1-24. [CrossRef] [PubMed]

56. Shirota, T.; He, H.; Yasui, H.; Matsuda, T. Human endothelial progenitor cell-seeded hybrid graft: Proliferative and antithrombogenic potentials in vitro and fabrication processing. Tissue Eng. 2003, 9, 127-136. [CrossRef] [PubMed]

57. Wang, H.; Riha, G.M.; Yan, S.; Li, M.; Chai, H.; Yang, H.; Yao, Q.; Chen, C. Shear stress induces endothelial differentiation from a murine embryonic mesenchymal progenitor cell line. Arterioscler. Thromb. Vasc. Biol. 2005, 25, 1817-1823. [CrossRef] [PubMed]

58. Brown, M.A.; Wallace, C.S.; Angelos, M.; Truskey, G.A. Characterization of umbilical cord blood-derived late outgrowth endothelial progenitor cells exposed to laminar shear stress. Tissue Eng. Part A 2009, 15, 3575-3587. [CrossRef] [PubMed]

59. Allen, J.B.; Khan, S.; Lapidos, K.A.; Ameer, G.A. Toward engineering a human neoendothelium with circulating progenitor cells. Stem Cells 2010, 28, 318-328. [CrossRef] [PubMed]

60. Angelos, M.G.; Brown, M.A.; Satterwhite, L.L.; Levering, V.W.; Shaked, N.T.; Truskey, G.A. Dynamic adhesion of umbilical cord blood endothelial progenitor cells under laminar shear stress. Biophys. J. 2010, 99, 3545-3554. [CrossRef] [PubMed]

61. Achneck, H.E.; Jamiolkowski, R.M.; Jantzen, A.E.; Haseltine, J.M.; Lane, W.O.; Huang, J.K.; Galinat, L.J.; Serpe, M.J.; Lin, F.H.; Li, M.; et al. The biocompatibility of titanium cardiovascular devices seeded with autologous blood-derived endothelial progenitor cells: EPC-seeded antithrombotic Ti implants. Biomaterials 2011, 32, 10-18. [CrossRef] [PubMed]

62. Sekiguchi, H.; Ii, M.; Jujo, K.; Yokoyama, A.; Hagiwara, N.; Asahara, T. Improved culture-based isolation of differentiating endothelial progenitor cells from mouse bone marrow mononuclear cells. PLoS ONE 2011, 6, e28639. [CrossRef] [PubMed]

63. Rössig, L.; Urbich, C.; Brühl, T.; Dernbach, E.; Heeschen, C.; Chavakis, E.; Sasaki, K.; Aicher, D.; Diehl, F.; Seeger, F.; et al. Histone deacetylase activity is essential for the expression of HoxA9 and for endothelial commitment of progenitor cells. J. Exp. Med. 2005, 201, 1825-1835. [CrossRef] [PubMed]

64. Yamamoto, K.; Sokabe, T.; Watabe, T.; Miyazono, K.; Yamashita, J.K.; Obi, S.; Ohura, N.; Matsushita, A.; Kamiya, A.; Ando, J. Fluid shear stress induces differentiation of Flk-1-positive embryonic stem cells into vascular endothelial cells in vitro. Am. J. Physiol. Heart Circ. Physiol. 2005, 288, H1915-H1924. [CrossRef] [PubMed]

65. Zeng, L.; Xiao, Q.; Margariti, A.; Zhang, Z.; Zampetaki, A.; Patel, S.; Capogrossi, M.C.; Hu, Y.; Xu, Q. HDAC3 is crucial in shear- and VEGF-induced stem cell differentiation toward endothelial cells. J. Cell. Biol. 2006, 174, 1059-1069. [CrossRef] [PubMed]

66. Ye, C.; Bai, L.; Yan, Z.Q.; Wang, Y.H.; Jiang, Z.L. Shear stress and vascular smooth muscle cells promote endothelial differentiation of endothelial progenitor cells via activation of Akt. Clin. Biomech. (Bristol, Avon) 2008, 23 (Suppl. 1), S118-S124. [CrossRef] [PubMed] 
67. Masumura, T.; Yamamoto, K.; Shimizu, N.; Obi, S.; Ando, J. Shear stress increases expression of the arterial endothelial marker ephrinB2 in murine ES cells via the VEGF-Notch signaling pathways. Arterioscler. Thromb. Vasc. Biol. 2009, 29, 2125-2131. [CrossRef] [PubMed]

68. Boon, R.A.; Urbich, C.; Fischer, A.; Fontijn, R.D.; Seeger, F.H.; Koyanagi, M.; Horrevoets, A.J.; Dimmeler, S. Kruppel-like factor 2 improves neovascularization capacity of aged proangiogenic cells. Eur. Heart J. 2011, 32, 371-377. [CrossRef] [PubMed]

69. Cui, X.; Zhang, X.; Guan, X.; Li, H.; Li, X.; Lu, H.; Cheng, M. Shear stress augments the endothelial cell differentiation marker expression in late EPCs by upregulating integrins. Biochem. Biophys. Res. Commun. 2012, 425, 419-425. [CrossRef] [PubMed]

70. Cheng, B.B.; Yan, Z.Q.; Yao, Q.P.; Shen, B.R.; Wang, J.Y.; Gao, L.Z.; Li, Y.Q.; Yuan, H.T.; Qi, Y.X.; Jiang, Z.L. Association of SIRT1 expression with shear stress induced endothelial progenitor cell differentiation. J. Cell. Biochem. 2012, 113, 3663-3671. [CrossRef] [PubMed]

71. Suzuki, Y.; Yamamoto, K.; Ando, J.; Matsumoto, K.; Matsuda, T. Arterial shear stress augments the differentiation of endothelial progenitor cells adhered to VEGF-bound surfaces. Biochem. Biophys. Res. Commun. 2012, 423, 91-97. [CrossRef] [PubMed]

72. Obi, S.; Masuda, H.; Shizuno, T.; Sato, A.; Yamamoto, K.; Ando, J.; Abe, Y.; Asahara, T. Fluid shear stress induces differentiation of circulating phenotype endothelial progenitor cells. Am. J. Physiol. Cell. Physiol. 2012, 303, C595-C606. [CrossRef] [PubMed]

73. Egorova, A.D.; DeRuiter, M.C.; de Boer, H.C.; van de Pas, S.; Gittenberger-de Groot, A.C.; van Zonneveld, A.J.; Poelmann, R.E.; Hierck, B.P. Endothelial colony-forming cells show a mature transcriptional response to shear stress. In Vitro Cell. Dev. Biol. Anim. 2012, 48, 21-29. [CrossRef] [PubMed]

74. Cheng, B.B.; Qu, M.J.; Wu, L.L.; Shen, Y.; Yan, Z.Q.; Zhang, P.; Qi, Y.X.; Jiang, Z.L. MicroRNA-34a targets Forkhead box $\mathrm{j} 2$ to modulate differentiation of endothelial progenitor cells in response to shear stress. J. Mol. Cell. Cardiol. 2014, 74, 4-12. [CrossRef] [PubMed]

75. Bai, Y.P.; Xiao, S.; Tang, Y.B.; Tan, Z.; Tang, H.; Ren, Z.; Zeng, H.; Yang, Z. Shear stress-mediated upregulation of GTP cyclohydrolase/tetrahydrobiopterin pathway ameliorates hypertension-related decline in reendothelialization capacity of endothelial progenitor cells. J. Hypertens. 2017, 35, 784-797. [CrossRef] [PubMed]

76. Yang, Z.; Tao, J.; Wang, J.M.; Tu, C.; Xu, M.G.; Wang, Y.; Pan, S.R. Shear stress contributes to t-PA mRNA expression in human endothelial progenitor cells and nonthrombogenic potential of small diameter artificial vessels. Biochem. Biophys. Res. Commun. 2006, 342, 577-584. [CrossRef] [PubMed]

77. Tao, J.; Yang, Z.; Wang, J.M.; Tu, C.; Pan, S.R. Effects of fluid shear stress on eNOS mRNA expression and NO production in human endothelial progenitor cells. Cardiology 2006, 106, 82-88. [CrossRef] [PubMed]

78. Sreerekha, P.R.; Krishnan, L.K. Cultivation of endothelial progenitor cells on fibrin matrix and layering on dacron/polytetrafluoroethylene vascular grafts. Artif. Organs 2006, 30, 242-249. [CrossRef] [PubMed]

79. Tao, J.; Yang, Z.; Wang, J.M.; Wang, L.C.; Luo, C.F.; Tang, A.L.; Dong, Y.G.; Ma, H. Shear stress increases $\mathrm{Cu} / \mathrm{Zn}$ SOD activity and mRNA expression in human endothelial progenitor cells. J. Hum. Hypertens. 2007, 21, 353-358. [CrossRef] [PubMed]

80. Yang, Z.; Wang, J.M.; Wang, L.C.; Chen, L.; Tu, C.; Luo, C.F.; Tang, A.L.; Wang, S.M.; Tao, J. In vitro shear stress modulates antithrombogenic potentials of human endothelial progenitor cells. J. Thromb. Thrombolysis 2007, 23, 121-127. [CrossRef] [PubMed]

81. Lund, T.; Hermansen, S.E.; Andreasen, T.V.; Olsen, J.O.; Østerud, B.; Myrmel, T.; Ytrehus, K. Shear stress regulates inflammatory and thrombogenic gene transcripts in cultured human endothelial progenitor cells. Thromb. Haemost. 2010, 104, 582-591. [CrossRef] [PubMed]

82. Gimbrone, M.A., Jr.; Garcia-Cardena, G. Endothelial Cell Dysfunction and the Pathobiology of Atherosclerosis. Circ. Res. 2016, 118, 620-636. [CrossRef] [PubMed]

83. Jensen, H.A.; Mehta, J.L. Endothelial cell dysfunction as a novel therapeutic target in atherosclerosis. Expert Rev. Cardiovasc. Ther. 2016, 14, 1021-1033. [CrossRef] [PubMed]

84. Cahill, P.A.; Redmond, E.M. Vascular endothelium - Gatekeeper of vessel health. Atherosclerosis 2016, 248, 97-109. [CrossRef] [PubMed]

85. Yurdagul, A., Jr.; Finney, A.C.; Woolard, M.D.; Orr, A.W. The arterial microenvironment: The where and why of atherosclerosis. Biochem. J. 2016, 473, 1281-1295. [CrossRef] [PubMed] 
86. Brown, R.A.; Shantsila, E.; Varma, C.; Lip, G.Y. Current understanding of atherogenesis. Am. J. Med. 2017, 130, 268-282. [CrossRef] [PubMed]

87. Metaxa, E.; Meng, H.; Kaluvala, S.R.; Szymanski, M.P.; Paluch, R.A.; Kolega, J. Nitric oxide-dependent stimulation of endothelial cell proliferation by sustained high flow. Am. J. Physiol. Heart Circ. Physiol. 2008, 295, H736-H742. [CrossRef] [PubMed]

88. Wang, C.; Baker, B.M.; Chen, C.S.; Schwartz, M.A. Endothelial cell sensing of flow direction. Arterioscler. Thromb. Vasc. Biol. 2013, 33, 2130-2136. [CrossRef] [PubMed]

89. Baeyens, N.; Mulligan-Kehoe, M.J.; Corti, F.; Simon, D.D.; Ross, T.D.; Rhodes, J.M.; Wang, T.Z.; Mejean, C.O.; Simons, M.; Humphrey, J.; et al. Syndecan 4 is required for endothelial alignment in flow and atheroprotective signaling. Proc. Natl. Acad. Sci. USA 2014, 111, 17308-17313. [CrossRef] [PubMed]

90. Dancu, M.B.; Berardi, D.E.; Vanden Heuvel, J.P.; Tarbell, J.M. Asynchronous shear stress and circumferential strain reduces endothelial NO synthase and cyclooxygenase-2 but induces endothelin-1 gene expression in endothelial cells. Arterioscler. Thromb. Vasc. Biol. 2004, 24, 2088-2094. [CrossRef] [PubMed]

91. Amaya, R.; Pierides, A.; Tarbell, J.M. The Interaction between fluid wall shear stress and solid circumferential strain affects endothelial gene expression. PLoS ONE 2015, 10, e0129952. [CrossRef] [PubMed]

92. Yang, Z.; Xia, W.H.; Zhang, Y.Y.; Xu, S.Y.; Liu, X.; Zhang, X.Y.; Yu, B.B.; Qiu, Y.X.; Tao, J. Shear stress-induced activation of Tie2-dependent signaling pathway enhances reendothelialization capacity of early endothelial progenitor cells. J. Mol. Cell. Cardiol. 2012, 52, 1155-1163. [CrossRef] [PubMed]

93. Wang, L.; Luo, J.Y.; Li, B.; Tian, X.Y.; Chen, L.; Huang, Y.; Liu, J.; Deng, D.; Lau, C.W.; Wan, S.; et al. Integrin-YAP/TAZ-JNK cascade mediates atheroprotective effect of unidirectional shear flow. Nature 2016, 540, 579-582. [CrossRef] [PubMed]

94. Wang, K.C.; Yeh, Y.T.; Nguyen, P.; Limqueco, E.; Lopez, J.; Thorossian, S.; Guan, K.L.; Li, Y.J.; Chien, S. Flow-dependent YAP/TAZ activities regulate endothelial phenotypes and atherosclerosis. Proc. Natl. Acad. Sci. USA 2016, 113, 11525-11530. [CrossRef] [PubMed]

95. Xu, S.; Koroleva, M.; Yin, M.; Jin, Z.G. Atheroprotective laminar flow inhibits Hippo pathway effector YAP in endothelial cells. Transl. Res. 2016, 176, 18-28.e2. [CrossRef] [PubMed]

96. Nigro, P.; Abe, J.; Berk, B.C. Flow shear stress and atherosclerosis: A matter of site specificity. Antioxid. Redox Signal. 2011, 15, 1405-1414. [CrossRef] [PubMed]

97. Hosoya, T.; Maruyama, A.; Kang, M.I.; Kawatani, Y.; Shibata, T.; Uchida, K.; Warabi, E.; Noguchi, N.; Itoh, K.; Yamamoto, M. Differential responses of the Nrf2-Keap1 system to laminar and oscillatory shear stresses in endothelial cells. J. Biol. Chem. 2005, 280, 27244-27250. [CrossRef] [PubMed]

98. Saxena, A.; Carninci, P. Whole-transcriptome analysis: What are we still missing? Wiley Interdiscip. Rev. Syst. Biol. Med. 2011, 3, 527-543. [CrossRef] [PubMed]

99. Costa, V.; Aprile, M.; Esposito, R.; Ciccodicola, A. RNA-Seq and human complex diseases: Recent accomplishments and future perspectives. Eur. J. Hum. Genet. 2013, 21, 134-142. [CrossRef] [PubMed]

100. Jiang, Z.; Zhou, X.; Li, R.; Michal, J.J.; Zhang, S.; Dodson, M.V.; Zhang, Z.; Harland, R.M. Whole-transcriptome analysis with sequencing: Methods, challenges and potential solutions. Cell. Mol. Life Sci. 2015, 72, 3425-3439. [CrossRef] [PubMed]

101. Fledderus, J.O.; van Thienen, J.V.; Boon, R.A.; Dekker, R.J.; Rohlena, J.; Volger, O.L.; Bijnens, A.P.; Daemen, M.J.; Kuiper, J.; van Berkel, T.J.; et al. Prolonged shear stress and KLF2 suppress constitutive proinflammatory transcription through inhibition of ATF2. Blood 2007, 109, 4249-4257. [CrossRef] [PubMed]

102. Aoki, T.; Yamamoto, K.; Fukuda, M.; Shimogonya, Y.; Fukuda, S.; Narumiya, S. Sustained expression of MCP-1 by low wall shear stress loading concomitant with turbulent flow on endothelial cells of intracranial aneurysm. Acta Neuropathol. Commun. 2016, 4, 48. [CrossRef] [PubMed]

103. Fledderus, J.O.; Boon, R.A.; Volger, O.L.; Hurttila, H.; Ylä-Herttuala, S.; Pannekoek, H.; Levonen, A.L.; Horrevoets, A.J. KLF2 primes the antioxidant transcription factor Nrf2 for activation in endothelial cells. Arterioscler. Thromb. Vasc. Biol. 2008, 28, 1339-1346. [CrossRef] [PubMed]

104. Lee, H.Y.; Youn, S.W.; Cho, H.J.; Kwon, Y.W.; Lee, S.W.; Kim, S.J.; Park, Y.B.; Oh, B.H.; Kim, H.S. FOXO1 impairs whereas statin protects endothelial function in diabetes through reciprocal regulation of Kruppel-like factor 2. Cardiovasc. Res. 2013, 97, 143-152. [CrossRef] [PubMed]

105. Gracia-Sancho, J.; Villarreal, G., Jr.; Zhang, Y.; García-Cardeña, G. Activation of SIRT1 by resveratrol induces KLF2 expression conferring an endothelial vasoprotective phenotype. Cardiovasc. Res. 2010, 85, 514-519. [CrossRef] [PubMed] 
106. Xu, Y.; Xu, S.; Liu, P.; Koroleva, M.; Zhang, S.; Si, S.; Jin, Z.G. Suberanilohydroxamic Acid as a Pharmacological Kruppel-Like Factor 2 Activator That Represses Vascular Inflammation and Atherosclerosis. J. Am. Heart Assoc. 2017, 6, e007134. [CrossRef] [PubMed]

107. Xu, Y.; Liu, P.; Xu, S.; Koroleva, M.; Zhang, S.; Si, S.; Jin, Z.G. Tannic acid as a plant-derived polyphenol exerts vasoprotection via enhancing KLF2 expression in endothelial cells. Sci. Rep. 2017, 7, 6686. [CrossRef] [PubMed]

108. Campolo, J.; Vozzi, F.; Penco, S.; Cozzi, L.; Caruso, R.; Domenici, C.; Ahluwalia, A.; Rial, M.; Marraccini, P.; Parodi, O. Vascular injury post stent implantation: Different gene expression modulation in human umbilical vein endothelial cells (HUVECs) model. PLoS ONE 2014, 9, e90213. [CrossRef] [PubMed]

109. Doddaballapur, A.; Michalik, K.M.; Manavski, Y.; Lucas, T.; Houtkooper, R.H.; You, X.; Chen, W.; Zeiher, A.M.; Potente, M.; Dimmeler, S.; et al. Laminar shear stress inhibits endothelial cell metabolism via KLF2-mediated repression of PFKFB3. Arterioscler. Thromb. Vasc. Biol. 2015, 35, 137-145. [CrossRef] [PubMed]

110. Riising, E.M.; Comet, I.; Leblanc, B.; Wu, X.; Johansen, J.V.; Helin, K. Gene silencing triggers polycomb repressive complex 2 recruitment to CpG islands genome wide. Mol. Cell 2014, 55, 347-360. [CrossRef] [PubMed]

111. Maleszewska, M.; Vanchin, B.; Harmsen, M.C.; Krenning, G. The decrease in histone methyltransferase EZH2 in response to fluid shear stress alters endothelial gene expression and promotes quiescence. Angiogenesis 2016, 19, 9-24. [CrossRef] [PubMed]

112. Li, Z.; Martin, M.; Zhang, J.; Huang, H.Y.; Bai, L.; Zhang, J.; Kang, J.; He, M.; Li, J.; Maurya, M.R.; Gupta, S.; et al. Krüppel-Like Factor 4 Regulation of Cholesterol-25-Hydroxylase and Liver X Receptor Mitigates Atherosclerosis Susceptibility. Circulation 2017, 136, 1315-1330. [CrossRef] [PubMed]

113. Hauser, S.; Jung, F.; Pietzsch, J. human endothelial cell models in biomaterial research. Trends Biotechnol. 2017, 35, 265-277. [CrossRef] [PubMed]

114. Qiao, C.; Meng, F.; Jang, I.; Jo, H.; Chen, Y.E.; Zhang, J. Deep transcriptomic profiling reveals the similarity between endothelial cells cultured under static and oscillatory shear stress conditions. Physiol. Genomics 2016, 48, 660-666. [CrossRef] [PubMed]

115. McCormick, M.E.; Manduchi, E.; Witschey, W.R.T.; Gorman, R.C.; Gorman, J.H., 3rd; Jiang, Y.Z.; Stoeckert, C.J., Jr.; Barker, A.J.; Yoon, S.; Markl, M.; et al. Spatial phenotyping of the endocardial endothelium as a function of intracardiac hemodynamic shear stress. J. Biomech. 2017, 50, 11-19. [CrossRef] [PubMed]

116. McCormick, M.E.; Manduchi, E.; Witschey, W.R.; Gorman, R.C.; Gorman, J.H., 3rd; Jiang, Y.Z.; Stoeckert, C.J., Jr.; Barker, A.J.; Markl, M.; Davies, P.F. Integrated Regional Cardiac Hemodynamic Imaging and RNA Sequencing Reveal Corresponding Heterogeneity of Ventricular Wall Shear Stress and Endocardial Transcriptome. J. Am. Heart Assoc. 2016, 5, e003170. [CrossRef] [PubMed]

117. Reitsma, S.; Slaaf, D.W.; Vink, H.; van Zandvoort, M.A.; oude Egbrink, M.G. The endothelial glycocalyx: Composition, functions, and visualization. Pflugers. Arch. 2007, 454, 345-359. [CrossRef] [PubMed]

118. Ajami, N.E.; Gupta, S.; Maurya, M.R.; Nguyen, P.; Li, J.Y.; Shyy, J.Y.; Chen, Z.; Chien, S.; Subramaniam, S. Systems biology analysis of longitudinal functional response of endothelial cells to shear stress. Proc. Natl. Acad. Sci. USA 2017, 114, 10990-10995. [CrossRef] [PubMed]

119. Öörni, K.; Rajamäki, K.; Nguyen, S.D.; Lähdesmäki, K.; Plihtari, R.; Lee-Rueckert, M.; Kovanen, P.T. Acidification of the intimal fluid: The perfect storm for atherogenesis. J. Lipid Res. 2015, 56, $203-214$. [CrossRef] [PubMed]

120. Huang, T.S.; Wang, K.C.; Quon, S.; Nguyen, P.; Chang, T.Y.; Chen, Z.; Li, Y.S.; Subramaniam, S.; Shyy, J.; Chien, S. LINC00341 exerts an anti-inflammatory effect on endothelial cells by repressing VCAM1. Physiol. Genomics 2017, 49, 339-345. [CrossRef] [PubMed]

121. Davies, P.F.; Remuzzi, A.; Gordon, E.J.; Dewey, C.F., Jr.; Gimbrone, M.A., Jr. Turbulent fluid shear stress induces vascular endothelial cell turnover in vitro. Proc. Natl. Acad. Sci. USA 1986, 83, 2114-2117. [CrossRef] [PubMed]

122. White, C.R.; Haidekker, M.; Bao, X.; Frangos, J.A. Temporal gradients in shear, but not spatial gradients, stimulate endothelial cell proliferation. Circulation 2001, 103, 2508-2513. [CrossRef] [PubMed]

123. Lerner-Marmarosh, N.; Yoshizumi, M.; Che, W.; Surapisitchat, J.; Kawakatsu, H.; Akaike, M.; Ding, B.; Huang, Q.; Yan, C.; Berk, B.C.; et al. Inhibition of tumor necrosis factor- $\alpha$-induced SHP-2 phosphatase activity by shear stress: A mechanism to reduce endothelial inflammation. Arterioscler. Thromb. Vasc. Biol. 2003, 23, 1775-1781. [CrossRef] [PubMed] 
124. Von Offenberg Sweeney, N.; Cummins, P.M.; Birney, Y.A.; Cullen, J.P.; Redmond, E.M.; Cahill, P.A. Cyclic strain-mediated regulation of endothelial matrix metalloproteinase-2 expression and activity. Cardiovasc. Res. 2004, 63, 625-634. [CrossRef] [PubMed]

125. Morrow, D.; Cullen, J.P.; Cahill, P.A.; Redmond, E.M. Cyclic strain regulates the Notch/CBF-1 signaling pathway in endothelial cells: Role in angiogenic activity. Arterioscler. Thromb. Vasc. Biol. 2007, 27, 1289-1296. [CrossRef] [PubMed]

126. Shimizu, N.; Yamamoto, K.; Obi, S.; Kumagaya, S.; Masumura, T.; Shimano, Y.; Naruse, K.; Yamashita, J.K.; Igarashi, T.; Ando, J. Cyclic strain induces mouse embryonic stem cell differentiation into vascular smooth muscle cells by activating PDGF receptor $\beta$. J. Appl. Physiol. (1985) 2008, 104, 766-772. [CrossRef] [PubMed]

127. Ando, J.; Yamamoto, K. Effects of shear stress and stretch on endothelial function. Antioxid. Redox Signal. 2011, 15, 1389-1403. [CrossRef] [PubMed]

128. Liu, H.B.; Zhang, J.; Xin, S.Y.; Liu, C.; Wang, C.Y.; Zhao, D.; Zhang, Z.R. Mechanosensitive properties in the endothelium and their roles in the regulation of endothelial function. J. Cardiovasc. Pharmacol. 2013, 61, 461-470. [CrossRef] [PubMed]

129. Zheng, J.; Zhang, K.; Wang, Y.; Cao, J.; Zhang, F.; Zhou, Q.; Dong, R. Identification of a microRNA signature in endothelial cells with mechanical stretch stimulation. Mol. Med. Rep. 2015, 12, 3525-3530. [CrossRef] [PubMed]

130. Dong, R.; Zhang, K.; Wang, Y.L.; Zhang, F.; Cao, J.; Zheng, J.B.; Zhang, H.J. MiR-551b-5p Contributes to pathogenesis of Vein Graft failure via upregulating early growth response-1 expression. Chin. Med. J. (Engl.) 2017, 130, 1578-1585. [CrossRef] [PubMed]

131. Cheng, M.; Guan, X.; Li, H.; Cui, X.; Zhang, X.; Li, X.; Jing, X.; Wu, H.; Avsar, E. Shear stress regulates late EPC differentiation via mechanosensitive molecule-mediated cytoskeletal rearrangement. PLoS ONE 2013, 8, e67675. [CrossRef] [PubMed]

132. Kingshott, P.; Andersson, G.; McArthur, S.L.; Griesser, H.J. Surface modification and chemical surface analysis of biomaterials. Curr. Opin. Chem. Biol. 2011, 15, 667-676. [CrossRef] [PubMed]

133. Bendrea, A.D.; Cianga, L.; Cianga, I. Review paper: Progress in the field of conducting polymers for tissue engineering applications. J. Biomater. Appl. 2011, 26, 3-84. [CrossRef] [PubMed]

134. Huang, N.F.; Lai, E.S.; Ribeiro, A.J.; Pan, S.; Pruitt, B.L.; Fuller, G.G.; Cooke, J.P. Spatial patterning of endothelium modulates cell morphology, adhesiveness and transcriptional signature. Biomaterials 2013, 34, 2928-2937. [CrossRef] [PubMed]

135. Takahashi, K.; Yamanaka, S. Induction of pluripotent stem cells from mouse embryonic and adult fibroblast cultures by defined factors. Cell 2006, 126, 663-676. [CrossRef] [PubMed]

136. Takahashi, K.; Tanabe, K.; Ohnuki, M.; Narita, M.; Ichisaka, T.; Tomoda, K.; Yamanaka, S. Induction of pluripotent stem cells from adult human fibroblasts by defined factors. Cell 2007, 131, 861-872. [CrossRef] [PubMed]

137. Yu, J.; Vodyanik, M.A.; Smuga-Otto, K.; Antosiewicz-Bourget, J.; Frane, J.L.; Tian, S.; Nie, J.; Jonsdottir, G.A.; Ruotti, V.; Stewart, R.; et al. Induced pluripotent stem cell lines derived from human somatic cells. Science 2007, 318, 1917-1920. [CrossRef] [PubMed]

138. Wernig, M.; Meissner, A.; Foreman, R.; Brambrink, T.; Ku, M.; Hochedlinger, K.; Bernstein, B.E.; Jaenisch, R. In vitro reprogramming of fibroblasts into a pluripotent ES-cell-like state. Nature 2007, 448, 318-324. [CrossRef] [PubMed]

139. Park, I.H.; Zhao, R.; West, J.A.; Yabuuchi, A.; Huo, H.; Ince, T.A.; Lerou, P.H.; Lensch, M.W.; Daley, G.Q. Reprogramming of human somatic cells to pluripotency with defined factors. Nature 2008, 451, 141-146. [CrossRef] [PubMed]

140. Narazaki, G.; Uosaki, H.; Teranishi, M.; Okita, K.; Kim, B.; Matsuoka, S.; Yamanaka, S.; Yamashita, J.K. Directed and systematic differentiation of cardiovascular cells from mouse induced pluripotent stem cells. Circulation 2008, 118, 498-506. [CrossRef] [PubMed]

141. Mauritz, C.; Schwanke, K.; Reppel, M.; Neef, S.; Katsirntaki, K.; Maier, L.S.; Nguemo, F.; Menke, S.; Haustein, M.; Hescheler, J.; et al. Generation of functional murine cardiac myocytes from induced pluripotent stem cells. Circulation 2008, 118, 507-517. [CrossRef] [PubMed]

142. Nakayama, K.H.; Joshi, P.A.; Lai, E.S.; Gujar, P.; Joubert, L.M.; Chen, B.; Huang, N.F. Bilayered vascular graft derived from human induced pluripotent stem cells with biomimetic structure and function. Regen. Med. 2015, 10, 745-755. [CrossRef] [PubMed] 
143. Sundaram, S.; One, J.; Siewert, J.; Teodosescu, S.; Zhao, L.; Dimitrievska, S.; Qian, H.; Huang, A.H.; Niklason, L. Tissue-engineered vascular grafts created from human induced pluripotent stem cells. Stem Cells Transl. Med. 2014, 3, 1535-1543. [CrossRef] [PubMed]

144. Gui, L.; Dash, B.C.; Luo, J.; Qin, L.; Zhao, L.; Yamamoto, K.; Hashimoto, T.; Wu, H.; Dardik, A.; Tellides, G.; et al. Implantable tissue-engineered blood vessels from human induced pluripotent stem cells. Biomaterials 2016, 102, 120-129. [CrossRef] [PubMed]

145. Sivarapatna, A.; Ghaedi, M.; Le, A.V.; Mendez, J.J.; Qyang, Y.; Niklason, L.E. Arterial specification of endothelial cells derived from human induced pluripotent stem cells in a biomimetic flow bioreactor. Biomaterials 2015, 53, 621-633. [CrossRef] [PubMed]

146. Sivarapatna, A.; Ghaedi, M.; Xiao, Y.; Han, E.; Aryal, B.; Zhou, J.; Fernandez-Hernando, C.; Qyang, Y.; Hirschi, K.K.; Niklason, L.E. Engineered Microvasculature in PDMS Networks Using Endothelial Cells Derived from HumanInduced Pluripotent Stem Cells. Cell. Transplant. 2017, 26, 1365-1379. [CrossRef] [PubMed]

147. Zhang, J.; Chu, L.F.; Hou, Z.; Schwartz, M.P.; Hacker, T.; Vickerman, V.; Swanson, S.; Leng, N.; Nguyen, B.K.; Elwell, A.; et al. Functional characterization of human pluripotent stem cell-derived arterial endothelial cells. Proc. Natl. Acad. Sci. USA 2017, 114, E6072-E6078. [CrossRef] [PubMed]

148. Belair, D.G.; Whisler, J.A.; Valdez, J.; Velazquez, J.; Molenda, J.A.; Vickerman, V.; Lewis, R.; Daigh, C.; Hansen, T.D.; Mann, D.A.; et al. Human vascular tissue models formed from human induced pluripotent stem cell derived endothelial cells. Stem Cell. Rev. 2015, 11, 511-525. [CrossRef] [PubMed]

149. Nakayama, K.H.; Hong, G.; Lee, J.C.; Patel, J.; Edwards, B.; Zaitseva, T.S.; Paukshto, M.V.; Dai, H.; Cooke, J.P.; Woo, Y.J.; et al. Aligned-braided nanofibrillar scaffold with endothelial cells enhances arteriogenesis. ACS Nano 2015, 9, 6900-6908. [CrossRef] [PubMed]

150. Kurokawa, Y.K.; Yin, R.T.; Shang, M.R.; Shirure, V.S.; Moya, M.L.; George, S.C. Human Induced Pluripotent Stem Cell-Derived Endothelial Cells for Three-Dimensional Microphysiological Systems. Tissue Eng. Part. C Methods 2017, 23, 474-484. [CrossRef] [PubMed]

151. Ellis, B.W.; Acun, A.; Can, U.I.; Zorlutuna, P. Human iPSC-derived myocardium-on-chip with capillary-like flow for personalized medicine. Biomicrofluidics 2017, 11, 024105. [CrossRef] [PubMed]

152. Youssef, A.A.; Ross, E.G.; Bolli, R.; Pepine, C.J.; Leeper, N.J.; Yang, P.C. The promise and challenge of induced pluripotent stem cells for cardiovascular applications. JACC Basic Transl. Sci. 2016, 1, 510-523. [CrossRef] [PubMed]

153. Xu, S. Transcriptome profiling in systems vascular medicine. Front. Pharmacol. 2017, 8, 563. [CrossRef] [PubMed]

(C) 2018 by the authors. Licensee MDPI, Basel, Switzerland. This article is an open access article distributed under the terms and conditions of the Creative Commons Attribution (CC BY) license (http://creativecommons.org/licenses/by/4.0/). 